\title{
The Effect of Using Picture Media Towards Students' Vocabulary Mastery at The Eighth Grade Students of Islamic Junior High School Students of Mathla'ul Anwar Dahu Bojong in Academic Year 2018/2019
}

\author{
Wahyu Wiganda Putra ${ }^{1}$
}

${ }^{1}$ English Education Study Program of Teacher Training and Education Faculty, Universitas Mathla'ul Anwar Banten

\section{ARTICLE INFO}

Keywords:

Picture Media

Vocabulary Mastery

\begin{abstract}
The purpose of this study is to investigate the effect of using picture media towards students' vocabulary mastery at the eighth grade students of MTs Mathla'ul Anwar Dahu Bojong which was located on Jl. Prapatan Warungkupa Km. $01 \mathrm{Kp}$ Dahu. Ds. Mekarsari Kec. Bojong Kab. Pandeglang, 42273. The population of this study was 50 students and the sample was 50 students. This study is carried out to find out whether there is a significant effect of using picture media towards students' vocabulary mastery. This research used a quantitative true experimental approach using PretestPosttest Control Group Design. In this research there are two variables, they are independent variable and dependent variable. The independent variable is Picture media $(\mathrm{X})$, and then the dependent variable is Vocabulary Mastery $(\mathrm{Y})$. In collecting the data this research used multiple choice test as instrument.The hypothesis analysis used analysis of t-test. In analysing the hypothesis this research used SPSS statistics 22 . Finding of this study showed that there is a significant effect of using picture media towards students' vocabulary mastery. It could be seen that $t$-count $=3.503$ and signification value ( $\mathrm{p}$-value) $=0.001<\alpha=0.05$, so H1 is accepted and $\mathrm{H} 0$ is rejected. On the other word, there is a significant effect of using picture media towards students' vocabulary mastery. Based on the result above, the researcher concluded that vocabulary is one of the elements in English. Teaching English using Picture Media gave positive contribution especially on improving vocabulary mastery.
\end{abstract}

\section{INTRODUCTION}

As an international language, English has a very important role, especially in the aspect of education. Consideration of the importance of this English language, the government decided to make this English as a subject taught from elementary school level up to university. The teaching

\footnotetext{
1 Corresponding author's address: English Education Study Program of Teacher Training and Education Faculty, Universitas Mathla'ul Anwar Banten, Banten, Indonesia

e-mail: wahyuwiganda20@gmail.com
} 
of English at each level would be different, as well as teaching at the junior high school level; students need learning with fun and enjoyable ways.

According to English curriculum, English has four skills, namely reading, speaking, listening and writing. These skills are supported by learning elements like structure, vocabulary, pronunciation and spellings. Vocabulary is one of the language components which have an important role in language learning. Without mastering enough vocabulary students are impossible to master the four English skills mentioned before, and then they also cannot speak or communicate in English well. Therefore, vocabulary is categorized as one of the important language elements which student should master. The mastery of vocabulary cannot sometimes be reached optimally without good media and method. Vocabulary includes collection of words. The words are known not only as individual words, but also a group of words that have meaning. The students will get difficulties in comprehending the text if they do not know the words in the text. Similarly in speaking, they will have same problem if they have only few vocabularies.

At the junior high school level, English is one of the compulsory subjects which are learned by the students; even it is one of the subjects which will be tested in National Final Examination. As in the school of MTs MA Dahu, the school has six classes which are separated into class XII, class XIII, and class IX. As the finding when the researcher went to that school at the first time to did the interview with the English teacher, the researcher finds out a few problem there, like the average of students' score are very low, the students' motivation in learning English too are very low. Most of the causes which cause them are relatively very low in English are dominated by weaknesses of mastering vocabulary. The weaknesses here are because the students feel difficult on memorizing vocabulary.

Furthermore, the limited media and monotonous teaching technique also are the cause of the problem happens. Teaching vocabulary to young learners is not easy. They have certain characteristic and need a certain treatment. Teachers play important role toward the success of vocabulary mastery. In this case, teachers need to develop, support, motivate, and dig up their basic ability in improving it by providing conducive environment, useful resources, and carefully structured input and practice opportunities. Young learners have specific learning needs. They learn best when they are involve and their works are valued, and they have opportunity to experiment for themselves.

Using picture is one of good media in teaching vocabulary. Through pictures, the students would be easier to comprehend what the teacher present. Picture is one of media that can be used to improve students' vocabulary mastery. It is also cheap and easy to be used to excite curiously of the language learners about the target language right from the beginning. For the students who study in junior high school, using picture as media are very useful and interesting in learning process because it will make the class more interactive and lively. Students will be highly motivated and a lot of fun during the class.

Based on the problems, the objective of the study is to investigate whether there is a significant effect of using picture media towards students' vocabulary mastery. The findings of the research are expected to be beneficial not only in theoretically but also in practically. First, in theoretical this study is expected has a benefit for language learning and teaching to be able to provide information dealing with the effect of using picture media in improving students' vocabulary mastery. Second, in practical, this research is expected has the benefits especially for the teachers, students, and institutions.

\section{Vocabulary}

According to Jack C. Richards and Willy A. Renandya (2002:255), "vocabulary is a core component of language proficiency and provides much of the basis for how well learners speak, listen, read, and write". It means that mastering vocabulary is very important, even if someone wants to learn English, he or she should master vocabulary first. By mastering vocabulary, he or she will be 
easier to comprehend English skill. On the other word, vocabulary is the most important subject in language learning. If someone vocabulary mastery is low, so he or she will be difficult in learning.

According to Hornby (2005:17), vocabulary is defined as a list of words with their meaning especially in a book for learning foreign language. It means that vocabulary is kind of the word which will make up a language. Vocabulary also is a basic element of language, and it has important role in language learning, even it is not less important than grammar.

Furthermore, according to Merriam-Researcherbster's Collegiate Dictionary (2003:1400), vocabulary is:

1. A list or collection of words and phrase usually alphabetically arranged and explained or defined.

2. A sum or stock of words employed by a language group individual or work or in a field of knowledge.

3. A list or collection of terms or codes available for use.

According to Cambridge Advanced Learner's Dictionary $3^{\text {rd }}$ edition, vocabulary is "all the words known and used by a particular person". It means that vocabulary is all the words which cover nouns, verbs, adjectives, adverb, and etc. (parts of speech) human used. Vocabulary is most importing teaching of language for the learners and makes the teaching of English Vocabulary have a very essential role in enabling the student to master the English as a first foreign language in Indonesia.

Based on the expert explanation above the researcher can say that vocabulary is a total of words or phrases which is used by people in communicating each other through a language. Vocabulary is the central of language. By mastering vocabulary, people would be easier to communicate each other in particular language.

There are many kinds of vocabulary, they are:

1. Based on the characteristics of the words

Ruth Gairns and Stuart Redman (1986:65) explain that vocabulary is divided into two kinds, they are:

a. Active vocabulary: refers to put items which the learners can use appropriately in speaking and writing. It is also called as a productive vocabulary. Active vocabularies are the words which researcher use in speaking and writing. These vocabularies are often called as productive vocabularies because they happen in speaking. These vocabularies should be pronounced well in order to avoid misunderstanding between listener and speaker. In writing, the writers have to be careful in using grammar and structure. They should use familiar vocabularies in order to avoid misunderstanding to the readers.

b. On the other hand, passive vocabulary refers to language items which could be recognized and understood in the context of reading and listening. It is called as respective vocabulary. It is used in two kinds of language skill, they are reading and listening.

2. Based on its form and function

John Read in his book, Assessing Vocabulary, mentioned two kinds of vocabulary based on its form and function, they are:

a. Function words

These are the words, which only have a full meaning when they are integrated with other word. It includes articles, preposition, pronouns, conjunctions, and auxiliaries.

b. Content words

These are the words, which have a full meaning and provide links within sentences. It includes nouns, verbs, adjective, and adverbs.

3. Used for communication 
S.H. Burton and J.A. Humphries in A.M. Zainuri (2003:1), there are two kinds of vocabularies used by people for communication, namely:

a. General vocabulary, it is the words used in general. There is no limited of fields or users, terms general that the writer means is general in meaning and using.

b. Special vocabulary, it is used in certain field, job, profession or special science. For example: politicians, journalists, and lawyers.

\section{Vocabulary Mastery}

Vocabulary mastery is the competence or complete knowledge of a list or a set of words that make up a language which might be used by a particular person, class, and profession (Napa, 1991:88). Vocabulary mastery is one component to master English as a foreign language in elementary, intermediate and advanced levels. In learning the four language skills (listening, speaking, reading, and writing), vocabulary is one basic component to be mastered. It is reasonable, remembering that the four language skills need knowledge of words because they will get nothing without vocabulary. The larger the students master vocabulary, the better they perform their language. By having too limited vocabulary, the students will find difficulties in mastering reading and other skills.

According to Norma (1995:17), Vocabulary mastery means the students having ability in understanding and using the vocabulary and know the meaning. There are 4 stages of the learner progress in mastery vocabulary: (a) progress extends from the beginning to the mastery of the fundamental of the structure and sounds system, (b) the vocabulary items should still consist of those that must be learned for production, (c) vocabulary mastery of recognition, (d) the choice of special areas of experience is necessary.

From the definition above, could be concluded that vocabulary mastery is competence to know words and meaning.

\section{Pictures}

According to Andrew Wright (1989:2), "Pictures are the most suitable for the revision of known language and more recombination or manipulation word, the pictures are not just an aspect of method but through their representation of places, object and people they are an essential part of the overall experiences"

Pictures are multipurpose resources to teach aspects of grammar. It is also could motivate the students to respond what the teacher teach because pictures are more than textbook or sentences on the board. Picture also can be used in various configurations to improve teaching and learning process. (Marianne Celce Murcia and Sharon Hilles, 1998:73). It means that picture has many benefits to help the students on understanding a new object because through picture, they can use their eyes to memorize the object easily.

In Oxford Advanced Learner's Dictionary $3^{\text {rd }}$ edition, "Picture is a drawing, painting or photograph, etc." It means that picture could be categorized as anything drawing, painting and photograph. It can be used in teaching and learning process.

Based on the definitions above, the researcher concludes that picture is anything drawing, painting, image, and photograph of an object. Picture could be used as media for teaching because it has many functions to make students easier in learning. Students will be more interesting and will be easier on memorizing the new words or objects in learning foreign language.

Furthermore, Betty Morgan Bowen (1973:13) mentions in her book that there are some types of picture, they are:

1. Wall charts, it illustrates aspect of a topic. On one chart used may be made by photograph, artist's drawing, symbols, graph, and text. 
2. Wall picture, it is simply a large illustration of scene or event. It is usually used in whole class. It is usually hung on the wall which illustrates things such as clouds, sea, mountains, sun, sky, etc. which are impossible to bring in to the class.

3. Flash cards, consists of two categories, they are word flashcard and picture flashcard. Word Flashcard is a printed word on it. It can be used to demonstrate what the teacher wishes. On the other hand, picture flashcard is a card which picture is on it. The picture shows the object or action.

4. Work cards, it is a card consists of picture/photo, image, map which indicate of identity of someone who has been worked in a company.

As mentioned above, there are many types of picture which could be used as media of teaching. Picture is very interesting aid for teaching, students will be more interested when teaching using picture as media.

Furthermore, Picure also has many advantages and disadvantages, Isaneni (2016) mention in his research paper that picture has many advantages as follows:

1. Picture can be used to stimulate students to make instructions. The student imagination will be increase when they have seen some object associated with the picture.

2. Picture can make students easier to understand the material. They easier to describe an object or pictures.

3. Picture can improve student's interest in learning vocabulary.

4. Picture can stimulate student's ability to speak up as well as possible.

The disadvantages of using picture as follows:

1. Picture needs more time in every meeting, while the time is limited.

2. Picture is impractical because teacher has to prepare it before.

3. Sometimes, teacher loses their ideas to keep the picture in line with topic to be taught.

Based on explanation above, using picture as teaching media has many advantages and disadvantages. It depends on how the picture is used. In short, using picture as teaching media is useful.

\section{METHOD}

This research used a quantitative true experimental approach using Pretest-Posttest Control Group Design (Sugiyono, 2009:75). In this design, the sample is grouped into two groups. They are chosen randomly, and then they are given pre-test in order to know their capability in the beginning whether there is difference between both of them. The lowest group in average score is taken as experimental class, while the higher group in average score is taken as control. This is aimed to see the powerful technique given. The objective of the research is to investigate the effect of Picture Media toward students' vocabulary mastery. In order to answer the research question, this research design is presented as follows:

Table 1. The True Experimental Design

\begin{tabular}{lccc}
\hline \multicolumn{4}{c}{ RESEARCH DESIGN } \\
\hline Experimental Group & O1 & $X$ & O2 \\
\hline Control Group & O3 & $X$ & O4 \\
\hline
\end{tabular}

Note:

O1: Pre-Test of Experimental Group

O2: Post-Test of Experimental Group

O3: Pre-Test of Control Group

O4: Post-Test of Control Group

$\mathrm{X}$ : Treatment 
Based on the design above, it shows that there are two variables in this research. They are independent variable and dependent variable. The independent variable is Picture media $(X)$, and then the dependent variable is Vocabulary Mastery $(\mathrm{Y})$.

Furthermore, the researcher used all population as sample. The researcher took two classes to investigate this study. They are experimental group and control group. The population of this research is 50 students, and the sample of this research is 50 students.

Table 2. The Data of Eight Grade Students of MTs MA Dahu Bojong

\begin{tabular}{cc}
\hline Class & Number of Sample \\
\hline Experimental & 25 Students \\
\hline Control & 25 Students \\
\hline Total & 50 Students \\
\hline
\end{tabular}

In this research the researcher used test as instrument to collect the data. The instrument was tested both validity and reliability. Vocabulary test was used to measure the students' vocabulary mastery. The form of the test is multiple choices. The test is divided into two sections of test. The first is pre-test and the second test is post-test.

Both experimental and control class were given pre-test and post-test. Pre-test was given to know how far the student's achievement in understanding vocabulary while Post-test was given to know the student's understanding after given the treatment using picture media.

The vocabulary test will be constructed based on the syllabus of curriculum 13. It was constructed into multiple choices. The question was taken around 30 questions which consist of nouns, verbs and adjectives. The vocabulary mastery blue print could be seen in the following table:

Table 3. The Vocabulary Mastery Blue Print

\begin{tabular}{|c|c|c|c|c|c|c|}
\hline No & Basic Competence & Indicator & Dimension & $\begin{array}{l}\text { Number of } \\
\text { Question }\end{array}$ & $\begin{array}{c}\text { Total } \\
\text { Questions }\end{array}$ & $\begin{array}{l}\text { Form of } \\
\text { the test }\end{array}$ \\
\hline \multirow[t]{4}{*}{1.} & \multirow{3}{*}{$\begin{array}{l}\text { Arrange oral and written } \\
\text { texts to state and ask about } \\
\text { the existence of an } \\
\text { insignificant number of } \\
\text { people, objects, animals, } \\
\text { taking into account social } \\
\text { functions, text structures, } \\
\text { and language elements that } \\
\text { are correct and in context. }\end{array}$} & \multirow{3}{*}{$\begin{array}{l}\text { Students are } \\
\text { able to know } \\
\text { some English } \\
\text { vocabularies } \\
\text { correctly } \\
\text { through } \\
\text { picture } \\
\text { media }\end{array}$} & Nouns & $\begin{array}{c}1,2,11,12,13, \\
17,18,19,20,21\end{array}$ & 10 & \multirow{4}{*}{$\begin{array}{l}\text { Multiple } \\
\text { choices }\end{array}$} \\
\hline & & & Verbs & $\begin{array}{c}3,5,7,8,9 \\
10,15,16,22,25,29\end{array}$ & 11 & \\
\hline & & & Adjectives & $\begin{array}{c}4,6,14,23,24 \\
26,27,28,30\end{array}$ & 9 & \\
\hline & \multicolumn{4}{|c|}{ Total Questions } & 30 & \\
\hline
\end{tabular}

Furthermore, the students' score was determined by dividing student's gained score by the maximum score, and then multiplied by the weight 100 . The formula is as follows:

$$
\text { Student's Score }=\frac{\text { Gained score }}{\text { Max score (30) }} \times 100
$$

\section{DISCUSSION}

The data in this research is the score of vocabulary test between two groups (experimental and control). Both of them were tested pre-test and post-test.

Table 4. Description of the data of Control Class

\begin{tabular}{cccc}
\hline No & Student's name & Pre-test & Post-test \\
\hline 1 & Respondent 1 & 73 & 83 \\
\hline 2 & Respondent 2 & 70 & 80 \\
\hline 3 & Respondent 3 & 80 & 86 \\
\hline
\end{tabular}




\begin{tabular}{cccc}
\hline 4 & Respondent 4 & 50 & 63 \\
\hline 5 & Respondent 5 & 63 & 70 \\
\hline 6 & Respondent 6 & 53 & 60 \\
\hline 7 & Respondent 7 & 70 & 86 \\
\hline 8 & Respondent 8 & 42 & 60 \\
\hline 9 & Respondent 9 & 70 & 70 \\
\hline 10 & Respondent 10 & 63 & 80 \\
\hline 11 & Respondent 11 & 42 & 63 \\
\hline 12 & Respondent 12 & 66 & 73 \\
\hline 13 & Respondent 13 & 50 & 60 \\
\hline 14 & Respondent 14 & 70 & 70 \\
\hline 15 & Respondent 15 & 40 & 40 \\
\hline 16 & Respondent 16 & 50 & 63 \\
\hline 17 & Respondent 17 & 63 & 73 \\
\hline 18 & Respondent 18 & 50 & 56 \\
\hline 19 & Respondent 19 & 80 & 83 \\
\hline 20 & Respondent 20 & 73 & 83 \\
\hline 21 & Respondent 21 & 63 & 70 \\
\hline 22 & Respondent 22 & 63 & 70 \\
\hline 23 & Respondent 23 & 60 & 76 \\
\hline 24 & Respondent 24 & 73 & 80 \\
\hline 25 & Respondent 25 & 53 & 60 \\
\hline & Total & 1530 & 1758 \\
\hline
\end{tabular}

Table 5. Description of the data of Experimental Class

\begin{tabular}{cccc}
\hline No & Student's name & Pre-test & Post-test \\
\hline 1 & Respondent 1 & 70 & 92 \\
\hline 2 & Respondent 2 & 66 & 76 \\
\hline 3 & Respondent 3 & 53 & 80 \\
\hline 4 & Respondent 4 & 70 & 86 \\
\hline 5 & Respondent 5 & 63 & 80 \\
\hline 6 & Respondent 6 & 60 & 90 \\
\hline 7 & Respondent 7 & 50 & 90 \\
\hline 8 & Respondent 8 & 50 & 60 \\
\hline 9 & Respondent 9 & 66 & 76 \\
\hline 10 & Respondent 10 & 83 & 90 \\
\hline 11 & Respondent 11 & 56 & 90 \\
\hline 12 & Respondent 12 & 60 & 90 \\
\hline 13 & Respondent 13 & 73 & 73 \\
\hline 14 & Respondent 14 & 60 & 66 \\
\hline 15 & Respondent 15 & 60 & 86 \\
\hline 16 & Respondent 16 & 70 & 90 \\
\hline 17 & Respondent 17 & 70 & 96 \\
\hline 18 & Respondent 18 & 40 & 80 \\
\hline 19 & Respondent 19 & 73 & 90 \\
\hline 20 & Respondent 20 & 60 & 73 \\
\hline 21 & Respondent 21 & 40 & 63 \\
\hline 22 & Respondent 22 & 46 & 80 \\
\hline 23 & Respondent 23 & 73 & \\
\hline & & & 83 \\
\hline
\end{tabular}




\begin{tabular}{cccc}
\hline 24 & Respondent 24 & 50 & 60 \\
\hline 25 & Respondent 25 & 66 & 86 \\
\hline & Total & 1528 & 2026 \\
\hline
\end{tabular}

The hypothesis test in this research used analysis of t-test. Before do further analysis, so this research needed to do Pre-Requirement of Research Analysis that covers normality and homogeneity test. The following table is the statistical analysis.

Table 6. The Statistical Analysis

\begin{tabular}{|c|c|c|c|c|c|c|c|}
\hline \multirow{4}{*}{ No } & \multirow{4}{*}{ Sample } & \multicolumn{6}{|c|}{ STATISTICS } \\
\hline & & \multirow{3}{*}{$\mathrm{N}$} & \multirow{3}{*}{ Mean } & \multirow{3}{*}{$\begin{array}{c}\text { Std. } \\
\text { Deviation }\end{array}$} & \multirow{2}{*}{ Normality } & \multirow{2}{*}{ Homogeneity } & Hypothesis \\
\hline & & & & & & & $p$-value \\
\hline & & & & & sig. & sig. & 1 \\
\hline 1. & Pre-test Control Class & 25 & 61.20 & 11.722 & 0.094 & \multirow{4}{*}{0.891} & \multirow{4}{*}{0.001} \\
\hline 2. & Post-Test Control Class & 25 & 70.32 & 11.205 & 0.200 & & \\
\hline 3. & Pre-test Experimental Class & 25 & 61.12 & 10.959 & 0.200 & & \\
\hline 4. & Post-Test Experimental Class & 25 & 81.04 & 10.418 & 0.077 & & \\
\hline Total & & 100 & 273.68 & 44.304 & & & \\
\hline
\end{tabular}

All the data shows normal and homogen. They could be seen from the sig. values $(0.094,0.200$, $0.200,0.077$ and 0.891 ) are higher than $\alpha=0.05$. The result showed that there is a significant effect of using Picture Media towards students' vocabulary mastery. Based on the calculation, the students who had been taught by using picture media is better than the students who had not been taught by picture media

Furthermore, in the previous studies also showed that each studies that have been conducted by Fauziah (2011) and Hidayah (2014), both of them claimed that the using of Picture Media in teaching English improved the students' vocabulary mastery. The results of those studies have endorsed the finding on what the researcher found in this study. Picture media are significantly improved the students' vocabulary mastery. Therefore, the result of this study shows that there is a significant effect of using Picture Media towards students' vocabulary mastery. This is because picture is appropriate media in teaching vocabulary.

Furthermore, from the number of students in both classes (VIII A and VII B), there are 50 students. They are 25 students in class VIII A and 25 students in class VIII B. Both of classes are given treatment. Class VIII A as experimental class was given the picture media in teaching process, while class VIII B as control class was given words in paper media. The Pre-test and Post-test were given to both classes.. From testing with $\mathrm{t}$-test obtained the $\mathrm{t}$-count $=3.503$ and signification value (p-value $)=0.001<\alpha=0.05$, so H1 is accepted and H0 is rejected. On the other word, there is a significant effect of using Picture Media towards students' vocabulary mastery.

\section{CONCLUSION}

Vocabulary is one of the elements in English. Teaching English using Picture Media gave positive contribution especially on improving vocabulary mastery. After conducting the research by giving pre-test and post-test to experimental class by using picture media and word media in paper in control class. The researcher found out there is a significant effect of using Picture Media towards students' vocabulary mastery.

\section{REFERENCES}

Thornbury, S. 2005.How to Teach Speaking. New York: Pearson Educational Ltd. Longman. 
Pervin, A. Lawrence and John P. Oliver.1997.Personality: Theory and Research. John Wiley and Sons, Inc: Canada.

Sri Minda Murni. 2012. Improving Students' Achievement in Speaking Through Paired Storytelling. Sibolga. Thesis

Rafiudin, D. 2011. The use of storytelling technique to improve students' speaking skill (a classroom action research at the first grade of SMA Negeri 1 Ngemplak). Boyolali. Paper

Anisa Anida. 2010. Improving Students' Speaking Through Storytelling Technique at the Tenth Grade of MAN 10 Joglo West Jakarta.UhamkaUniversity. Paper

Anwar. Choiril. 2013. The Effectiveness of Using Role-play and Show-and-tell in the Speaking Skills of Grade 5 Students of Elementary School. http://eprints.uny.ac.id/11057/1/Abstrak_Choiril_Anwar.pdf. Yogyakarta. Thesis. Retrieved Friday $20^{\text {th }}$ June 2014, 4:20 pm

Muhammad Novi Ibrahim.2012.The Effect of students' Vocabulary Learning Strategies And Learning Styles on Their Vocabulary Mastery.Jakarta. Uhamka University. Thesis

Herbert, H. Clark \& Eve, V. Clark. 1977. Psychology and Language. New York.USA: HBJ.

Brown, H. Douglas. 2001. Teaching by Principles. Sanfrancisco: Longman

http://bbutm.weebly.com/uploads/1/3/2/9/13290838/techniquesteachingspeakingnotes.

Gabriel, Byrne. 1990. Listening to Spoken English Problem. Second edition. Harlow. Longman.

Brown, H. Douglas. 2004. Teaching by Principles. Sanfrancisco: Longman.

http://www.ebooklibs.com/view.php?file=http://symtommedia.com/wp-content/uploads/teachingresource.pdf.2012

Carol J. Fisher and C. Ann Terry. 1997. Children's Language and The Language Arts.

New York: McGraw-Hill Inc.

Barzaq, Maynard. 2009. Integrating Sequential Thinking Through Teaching Stories in Curriculum.Journal of action Research Al-Qattan Center for Educational Research and Development

B, Maynard. 2005. The Important of Story. Available in: http://subversiveinfluence.com/2005/01/the Important of Story.

Katherin Ploeger. 2005. Simplified paragraph of Narrative Short Story. Listening Skill.

Margaret Pogemiller Covvey. 1987. Communication Through Listening. United State of America.Prentice-Hall.

Yellen, Blake, \& DeVries. 2004. Developing Speaking Skills;Notes from Integrating the Language Arts, $3^{\text {rd }}$ $E d$. Holcomb Hathaway Publishers, Scottsdale, AZ

http://www.earlychildhoodnews.com/earlychildhood/article_home.aspx?ArticleID=749

Karl Smith. 1995. Strategies for effective teaching: a handbook for teaching assistants. University of Wisconsin.

http://www.brighthubeducation.com/teaching-elementary-school/16204-benefits-of-show-and-tell/ http://www.earlychildhoodnews.com/earlychildhood/article_home.aspx?ArticleID=749

Rebecca, L. Oxford. 2003. Language learning Styles and strategies; an overview. Learning Styles $\mathcal{E}$ Strategies/Oxford, Gala. 
Oliver P. Jhon et al.2008. Handbook of Personality Theory and Research. Third edition. The Guilford Press. New York.

Zoltan, D. 2005. The Psychology of the Language Learner. Lawrence Erlbaum Associates. London. Pervin, L. A., \& John, O. P. 2001. Personality: Theory and research (8th ed.). New York

Mania Rosnatinia, The effect of personality type, learning styles and strategies on Iranian MA EFLLearners. Islamic Azad University, Teheran-Iran

Fiest Jess \& J. Fiest Gregory. 2006. Theories of personality. New York: McGraw Hill Companies.

Fraenkel, R, Jack and Wallen. E Norman 2012. How to Design and Evaluate Research in Education: Eight Edition. New York: Eight Edition : Mc Graw-Hill Companies.

Florence Littauer.1996.Personality Plus. Revision Edition. Binarupa Aksara.

Felicitas Heyne. 2009. The iPersonic Personality Test. http://www.ipersonic.com/test.html. http://funtestiq.com/personality/personalitytest39.shtml.

William E. Arnold James C. Mccroskey \& Samuel V.O Prichard, 2011. The Likert Type Scale. http//: www.jamescmccroskey.com/publication.

Fahrur Rozi. 2006. "The Relationship Between the Mastery Of Sentence Stress, Grammar and the Oral Presentation of Medical Record In English," (Thesis of Post-Graduate Program State University Of Semarang, 2006)

Brown D. 2004. Language assessment: Principle adn classroom practice. New York: Pearson Education, Inc.

J.B, Heaton. 1995. Writing Language Test: A Practical Guide for Teachers of English as a Second or Foreign Language, London: Longman.

Richard J. \& Renandya W.A. 2002. Methodology in Language Teaching. USA. Cambridge University Press.

Littauer F. 1992. Personality Plus.

Suparman, U. 2010.The Theory of Second Language Acquisition. CV Arfino Raya, Bandung.

Jeremy Harmer. 2007. The Practice of English Language Teaching. Great Britain: Pearson Education Limited, $4^{\text {th }} \mathrm{Ed}$ 